\title{
The diagnosis and treatment of a symptomatic mesenteric cyst
}

\author{
Simon Rajendran, ${ }^{1}$ Ata Khan, ${ }^{2}$ Micheal Murphy, ${ }^{3}$ Deirdre O'Hanlon ${ }^{4}$
}

${ }^{1}$ Department of Surgery, Royal College of Surgeons, Dublin, Ireland

${ }^{2}$ Department of Surgery, South Infirmary Victoria University Hospital, Cork, Ireland

${ }^{3}$ Department of Radiology, South Infirmary Victoria University Hospital, Cork, Ireland

${ }^{4}$ Department of General Surgery, South Infirmary Victoria University Hospital, Cork, Ireland

Correspondence to Dr Simon Rajendran, simonrajendran@gmail.com

Accepted 8 April 2014
CrossMark

To cite: Rajendran $S$, Khan A, Murphy M, et al. BMJ Case Rep Published online: [please include Day Month Year] doi:10.1136/ bcr-2013-202410

\section{DESCRIPTION}

The diagnosis and treatment of mesenteric cysts is challenging due to rarity, lack of specific symptoms and variability in location and size. This report aims to discuss current diagnostic and treatment strategies. A 35-year-old woman presented with non-specific abdominal pain. CT revealed a $5 \times 5 \times 3 \mathrm{~cm}$ septated abdominal cyst (figure 1). Aspiration (figure 1) demonstrated no malignant cells. Return of symptoms confirmed recurrence using MRI 2 months later (figure 2). Laparotomy confirmed $5 \mathrm{~cm}$ cyst attached to ileal mesentery (figure 3). Cyst was excised intact (figure 3). Histology showed multilocular cyst lined by mullerian epithelium. Symptoms resolved with no evidence of recurrence 3 months later (figure 1). Mesenteric cysts, described by Benevenni in 1507, arise from duodenal to sigmoid mesentery. They generally cause non-specific symptoms or rarely rupture, tort and obstruct. They result from lymphatic malformation, occult trauma or infection. Differential diagnosis includes ovarian, duplication or pseudocysts. Careful interpretation of imaging is important for preoperative planning. Ultrasound can be useful as primary imaging modality. Although CT was performed in our case, taking into account the age of the female patient, MRI is advised for further anatomic localisation and guidance for aspiration. ${ }^{1}$ Treatment is indicated for symptoms. While there is lack of evidence correlating size with complications it is likely that increasing size will increase the risk of complications. ${ }^{2}$

\section{Learning points}

Mesenteric cysts, a rare cause of abdominal pain, can arise from the mesentery of the duodenum to the sigmoid colon.

- Preoperative imaging requires careful interpretation for accurate anatomical localisation.

- Complete excision by either laparoscopic or open technique is the treatment of choice for symptomatic mesenteric cysts.
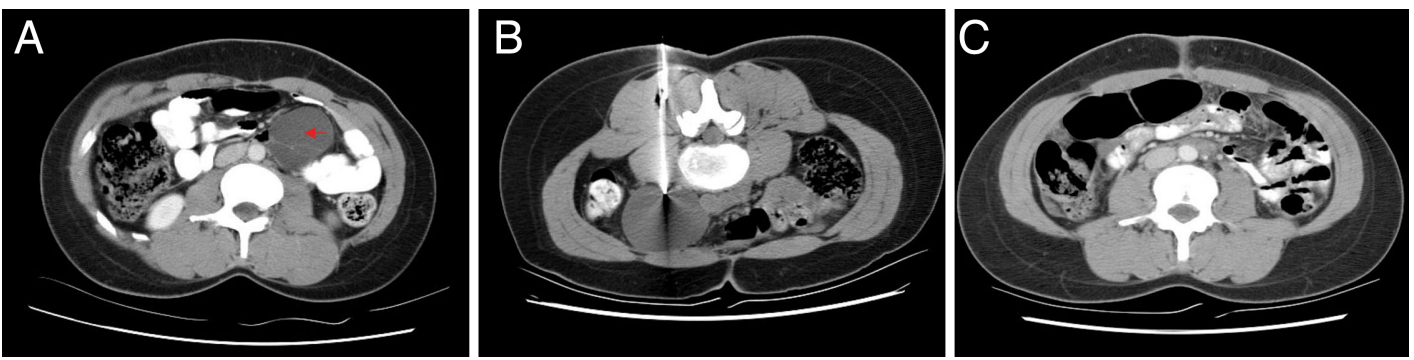

Figure 1 Axial CT images demonstrating (A) $5 \times 5 \times 3 \mathrm{~cm}$ septated cyst (red arrow). (B) CT-guided drainage of cyst. (C). No evidence of recurrence following surgical resection.

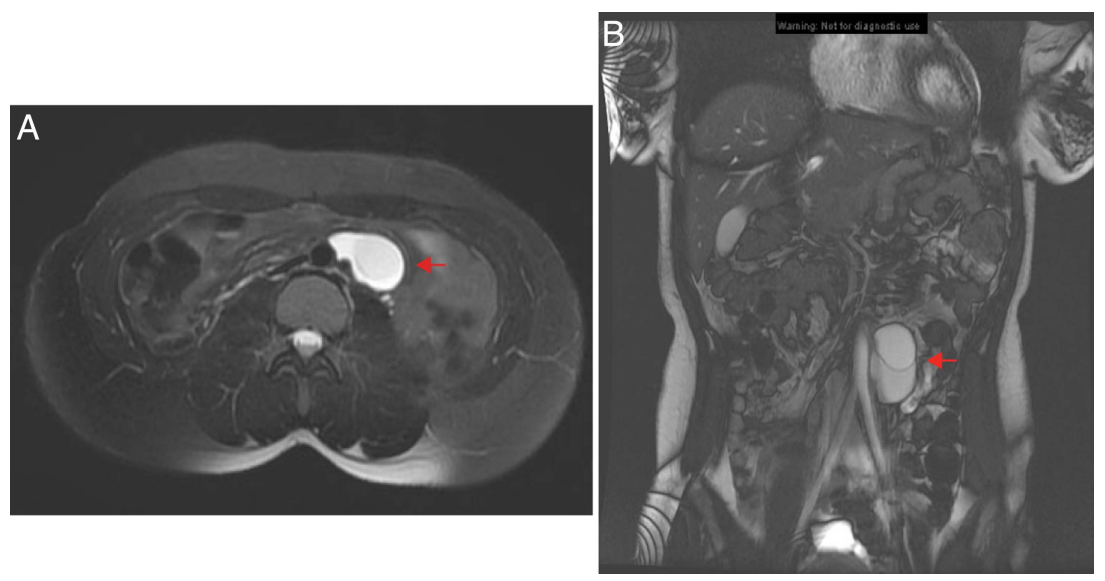

Figure 2 (A) Axial and (B) coronal MRI demonstrating cystic mass in close relation with aorta and extending into ileal mesentery. 

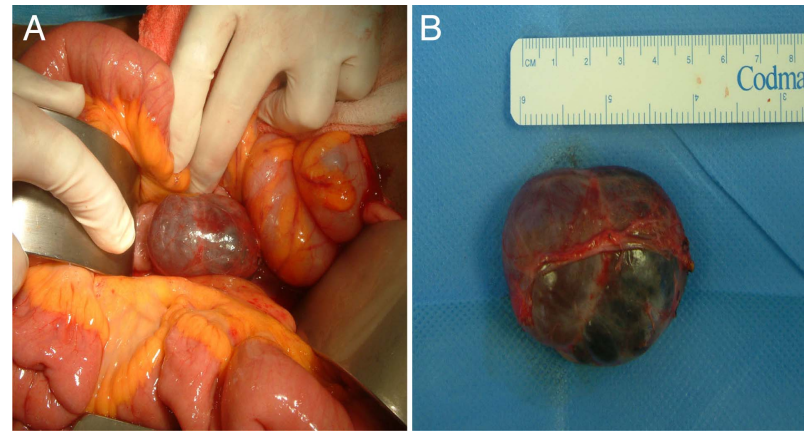

Figure 3 (A) Intraoperative image demonstrating reddish-blue cyst deriving from the mesentery of the small intestine. (B) Completely excised $5 \mathrm{~cm}$ mesenteric cyst.

Complete excision by laparoscopic or open technique is gold standard while simple aspiration or marsupialisation demonstrate higher recurrence rates. While follow-up periods in the literature ranged from 3 to 48 months using ultrasound imaging, ${ }^{3}$ there appears to be minimal benefits in long-term follow-up as recurrence is rare and generally occurs early.

Acknowledgements The authors thank South Infirmary Victoria University Hospital.

Contributors All the authors have contributed to the management of the patient and drafting the manuscript.

Competing interests None.

Patient consent Obtained.

Provenance and peer review Not commissioned; externally peer reviewed.

\section{REFERENCES}

1 Bhandarwar AH, Tayade MB, Borisa AD, et al. Laparoscopic excision of mesenteric cyst of sigmoid mesocolon. J Minim Access Surg 2013;9:37-9.

2 Nam SH, Kim DY, Kim SC, et al. The surgical experience for retroperitoneal, mesenteric and omental cyst in children. J Korean Surg Soc 2012;83:102-6.

3 Zeiler M, Santarelli S, Cangiotti AM, et al. Giant mesenteric cyst of mesothelial origin in a haemodialysis patient with previous peritoneal dialysis therapy. Nephrol Dialysis Transplant 2010;25:1004-6.

Copyright 2014 BMJ Publishing Group. All rights reserved. For permission to reuse any of this content visit

http://group.bmj.com/group/rights-licensing/permissions.

BMJ Case Report Fellows may re-use this article for personal use and teaching without any further permission.

Become a Fellow of BMJ Case Reports today and you can:

- Submit as many cases as you like

- Enjoy fast sympathetic peer review and rapid publication of accepted articles

- Access all the published articles

- Re-use any of the published material for personal use and teaching without further permission

For information on Institutional Fellowships contact consortiasales@bmjgroup.com

Visit casereports.bmj.com for more articles like this and to become a Fellow 